\title{
Factor Affecting Textile Dye Removal Using Adsorbent From Activated Carbon: A Review
}

\author{
Mohd Adib Mohammad Razi ${ }^{1, *}$, Mimi Nur Attahirah Mohd Hishammudin ${ }^{1}$ and Rafidah \\ Hamdan $^{2}$ \\ ${ }^{1}$ Faculty of Civil Engineering and Environmental, Universiti Tun Hussein Onn Malaysia, 86400 Batu \\ Pahat, Johor \\ ${ }^{2}$ Faculty of Engineering Technology, Uniersiti Tun Hussein Onn Malaysia, 86400 Batu Pahat, Johor
}

\begin{abstract}
Industrial company such as textile, leather, cosmetics, paper and plastic generated wastewater containing large amount of dye colour. The removal of dye materials are importance as the presence of this kind of pollutant influence the quality of water and makes it aesthetically unpleasant. As their chemical structures are complicated, it is difficult to treat dyes with municipal waste treatment operations. Even a small quantity of dye does cause high visibility and undesirability. There have been various treatment technique reviewed for the removal of dye in wastewater. However, these treatment process has made it to another expensive treatment method. This review focus on the application of adsorbent in dye removal from textile wastewater as the most economical and effective method, adsorption has become the most preferred method to remove dye. The review provides literature information about different basis materials used to produce activated carbon like agricultural waste and industrial waste as well as the operational parameters factors in term of contact time, adsorbent dosage, $\mathrm{pH}$ solution and initial dye concentration that will affect the process in removing textile dye. This review approach the low cost and environmental friendly adsorbent for replacing conventional activated carbon.
\end{abstract}

\section{Introduction}

Textile industries processes are among the most industrial that release coloured wastewater containing dye that become major environmental concern. Without a proper treatment, the disposal of dye wastewater can cause harm for the aquatic species and environment. [1]. Therefore, wastewater from textile industry has to be treated before being discharged into the environment. The textile industry is classified into three main categories as in Table 1. Dye is a coloured substance that been used widely in textile industries which provide bright and lasting colour when binding with fabric or surface. Dye was estimated to be used for thousands year back and about 180,000 year ago, colorant is believed to be use earliest by Neanderthal [2]. Synthetic dyes gained huge popularity in textile and dyeing process because of their stability to light, temperature, detergent and variety in colour [3]. In fact, it

${ }^{1}$ Corresponding author: adib@uthm.edu.my 
has reached nearly 100,000 different types of dyes and annually produce over $7.0 \times 10^{5}$ tonnes per year worldwide [3-8].

Table 1.Fibre and fabric categories for textile industries.

\begin{tabular}{|l|l|l|l|}
\hline Fibres & Fabric & Type of dye and chemical & Ref. \\
\hline Cellulose & $\begin{array}{l}\text { Cotton, rayon, linen, ramie, } \\
\text { hemp and lyocell }\end{array}$ & $\begin{array}{l}\text { Reactive dyes (remazol, procion MX } \\
\text { and cibaxron F). direct dyes (congo red, } \\
\text { direct yellow 50 and direct brown 116), } \\
\text { naphthol dyes (fast yellow GC, fast } \\
\text { scarlet R and fast blue B) and indigo } \\
\text { dyes (indigo white, tyrisn purple and } \\
\text { indigo carmine) }\end{array}$ & [9] \\
\hline Protein & $\begin{array}{l}\text { Wool, angora, mohair, } \\
\text { cashmere and silk }\end{array}$ & $\begin{array}{l}\text { Acid dyes (azo dyes, triarylmethane } \\
\text { dyes and anthraquinone dyes) and } \\
\text { lanaset dyes (Blue 5G and Bordeaux B) }\end{array}$ & \\
\hline Synthetic & $\begin{array}{l}\text { Polyester, nylon, spandex, } \\
\text { acetate, acrylic, ingeo and } \\
\text { polyproplylene }\end{array}$ & $\begin{array}{l}\text { Dispersed dyes (disperse yellow 218 } \\
\text { and disperse navy 35), basic dyes (basic } \\
\text { orange 37 and basic red 1) and direct } \\
\text { dyes }\end{array}$ & \\
\hline
\end{tabular}

Loss of up to $40 \%$ dye during the dyeing process are the result of coloured wastewater that passed into the environment or treatment plants [10]. The coloured wastewater are unpleasant and heavily pollute the environment. Dyes present in industrial wastewater are carcinogenic, mutagenic, teratogenic and toxic [11]. In addition, most of dye leads to hazardous affects not only to animal and human health but also microorganisms [12-14]. Dye have complex aromatic molecular structures and stable towards heat and oxidizing agent $[14,15]$. Therefore, dyes removal is prime important issue for researchers. Recently, many different techniques such as biological treatment [16], nanofiltration, oxidation process, ion exchanges, ozonations, ultrafiltration, coagulation, etc. have been studied for the treatment of dyes from wastewater [12,17-19]. However, these processes are expensive and ineffective to treat huge range of wastewater unlike adsorption using activated carbon which is proven to be one of the most effective technique [20].

Adsorption process is among the famous process that been studied by researchers. Adsorption is effective in removing colour and soluble organic pollutants include organic dye, toxic chemical, phenol, pesticides and cyanides [18,21]. The most used adsorbent in removing colours and other pollutants include heavy metal from effluents is activated carbon. However, conventional activated carbon that been used today are expensive for a large scale of treatment [21-23]. Recently, the researchers has been focus on the development of low cost adsorbent for a full scale treatment [5,24,25]. Therefore, this review provide comprehensive information on the application of activated carbon for the treatment of dye and study the effect of adsorption factors towards dye removal.

\section{Textile dye}

Commercially, more than 100,000 dye are used and available in colour index today [19]. Dye are stable to light [26] and can be classified in several ways based on their structures, application method used or even by colour [27]. The common dyes applied in textile industries are classed as direct dye, acid dye, basic dye, mordant dye, azo dye, reactive dye, disperse dye, sulphur dye, vat dye [28]. Nowadays, the classification of dye in term of application used in dyeing process are often. In addition, dye can also be classified by their 
solubility in water [29] or else by their particle charge during dissolution such as anionic dyes (reactive, direct and acid dye), cationic dye (basic dye) and also non-ionic dye (disperse dye) [30]. In addition, anionic and cationic dye including in water soluble dye while non-ionic dye is in the categories of water insoluble dye.

Reactive dye been design for cellulose fiber and contain high colour of organic substance [31]. This reactive dye have high solubility in water and the most permanent dye among others dye [32]. As for direct dye from azo group, these dye provide dull colour and is lightfast as compared to reactive dye. Some azo direct dye may contain benzidine-based dye that could result an exposure to allergies, irritation, cancer risk and treating aquatic life if they are directly release without any treatment. Back then, benzidine-based dye are used to colour textile, leather, wood, paper, plastic, fur and cosmetic industries [33]. As for worldwide textile industries, dye are discharged more than 1000 tones/year into waste stream [5,34]. Consequently, these textile wastewater containing benzidine-based dye may cause major damage to ecosystem including loss of soil productivity, disturbing the oxygen transfers in water interface and also interrupt photosynthesis activity.

\section{Classification of adsorbent}

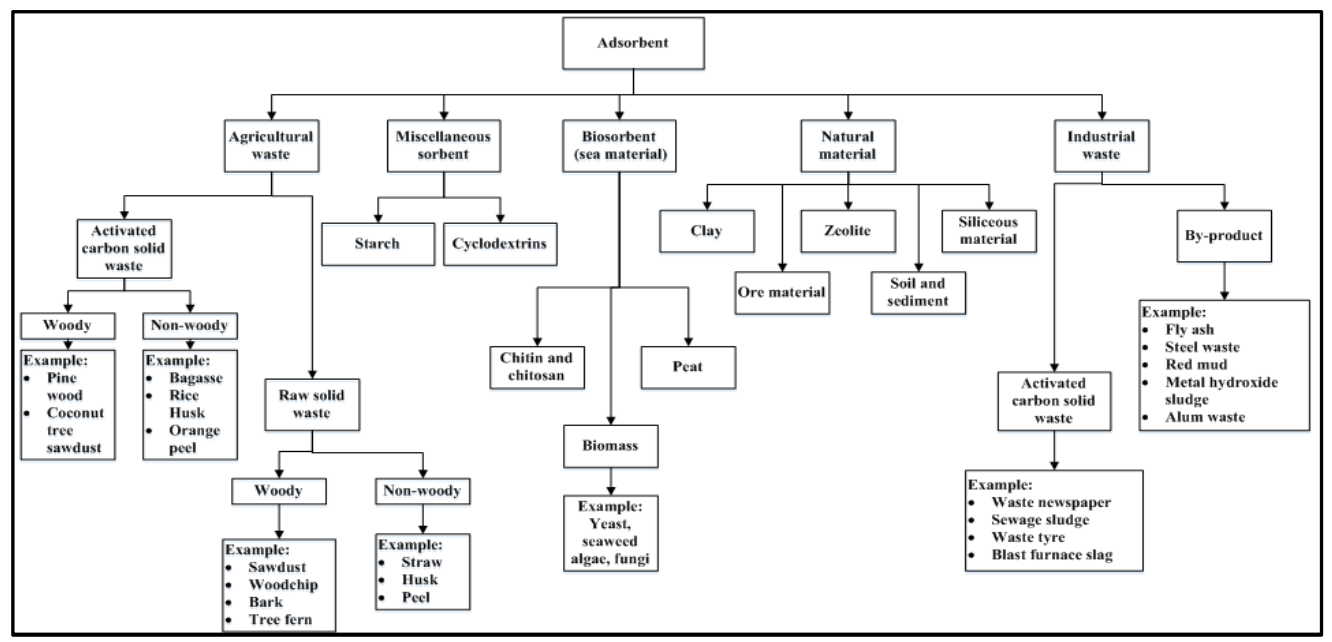

Fig. 1. Type of adsorbent materials used for wastewater treatment. [24,25]

Among several wastewater treatment process, adsorption have the potential in reducing water pollutants and dyes from textile industries. Adsorption is effective to be used in lowering dye concentration in the effluents [35-36]. Fig. 1 shown various type of adsorbent being studied in order to treat wastewater containing dye, pigments and other pollutants. Today, the most commonly adsorbent used for treatment is activated carbon [37] and applied for various water pollutant removal such as dye and heavy metal [35,38]. Activated carbon also known as solid sponge [39] is a carbon form by using either physical or chemical treatment [40]. Activated carbon have extended surface area, high capacity of adsorption, higher surface reactivity degree and also micro-pore structure which is suitable in eliminating dye from wastewater [41-43]. However, treating wastewater by using conventional activated carbon that is available in the market are expensive [1, 5, 31, 43-44] and its regeneration are even costly [26]. Therefore, various raw material have been 
examined to produce activated carbon and each presents different properties as some previous research of adsorbent shown in Table 2.

Table 2. Previous research on adsorbent in removing dye from wastewater.

\begin{tabular}{|l|l|c|c|}
\hline \multicolumn{1}{|c|}{ Adsorbent } & \multicolumn{1}{|c|}{ Type of dye } & $\begin{array}{c}\text { Max Adsorption } \\
\text { Capacity }\end{array}$ & Ref. \\
\hline Date pits activated carbon & Methylene blue & $244 \mathrm{mg} / \mathrm{g}$ & {$[20]$} \\
\hline Date pits activated carbon & Remazol yellow & $173 \mathrm{mg} / \mathrm{g}$ & {$[20]$} \\
\hline $\begin{array}{l}\text { Nickel doped zinc sulphide activated } \\
\text { carbon }\end{array}$ & Congo red & $285.714 \mathrm{mg} / \mathrm{g}$ & {$[45]$} \\
\hline $\begin{array}{l}\text { Palladium nanoparticles activated } \\
\text { carbon }\end{array}$ & Congo red & $126.58 \mathrm{mg} / \mathrm{g}$ & {$[45]$} \\
\hline Myrtus communis activated carbon & Congo red & $19.231 \mathrm{mg} / \mathrm{g}$ & {$[1]$} \\
\hline Pomegranate activated carbon & Congo red & $10 \mathrm{mg} / \mathrm{g}$ & {$[1]$} \\
\hline Argemone Mexicana & Direct red 81 & $6.9 \times 10-5 \mathrm{~mol} / \mathrm{g}$ & {$[46]$} \\
\hline Grape marc-based activated carbon & Reactive Black 5 & $333 \mathrm{mg} / \mathrm{g}$ & {$[47]$} \\
\hline TiO2/GMAC & Reactive Black 5 & $56 \mathrm{mg} / \mathrm{g}$ & {$[47]$} \\
\hline Pomegranate peel activated carbon & Remazol Brilliant Blue & $370.86 \mathrm{mg} / \mathrm{g}$ & {$[32]$} \\
& R & $170.33 \mathrm{mg} / \mathrm{g}$ & {$[26]$} \\
\hline Bagasse fly ash & Malachite green & $8.27 \mathrm{mg} / \mathrm{g}$ & {$[26]$} \\
\hline Activated carbon commercial grade & Malachite green & $42.18 \mathrm{mg} / \mathrm{g}$ & {$[26]$} \\
\hline Activated carbon laboratory grade & Malachite green & $61.72 \mathrm{mg} / \mathrm{g}$ & {$[14]$} \\
\hline Phoenix dactylifera seeds & Congo red & $198 \mathrm{mg} / \mathrm{g}$ & {$[48]$} \\
\hline Sugarcane bagasse activated carbon & Methylene blue & $9.57 \mathrm{mg} / \mathrm{g}$ & {$[49]$} \\
\hline Spent tea leaves & Brilliant green, & $4.8 \mathrm{mg} / \mathrm{g}$ & \\
\hline Jackfruit peels & Porcion red & $9.47 \mathrm{mg} / \mathrm{g}$ & {$[49]$} \\
\hline Rambutan peels & Brilliant green, & $6.12 \mathrm{mg} / \mathrm{g}$ & {$[49]$} \\
& Porcion red & $9.64 \mathrm{mg} / \mathrm{g}$ & {$[49]$} \\
\hline Mangosteen peels & Brilliant green, & $4.12 \mathrm{mg} / \mathrm{g}$ & {$[.27 \mathrm{mg} / \mathrm{g}$} \\
\hline Porcion red & $4.51 \mathrm{mg} / \mathrm{g}$ & {$[49]$} \\
\hline & $\begin{array}{l}\text { Brilliant green, } \\
\text { Porcion red }\end{array}$ & $384.6 \mathrm{mg} / \mathrm{g}$ & {$[38]$} \\
\hline
\end{tabular}

\subsection{Agricultural waste}

Adsorbent produce from agricultural waste is cheap and can be divided onto two groups: i) activated carbon ii) solid waste which from raw agricultural waste and material waste from forest industries. Various studied by researchers has been conduct on raw and activated carbon agricultural waste [50] such as sugarcane bagasse [8,18,50-55], olive stone [56], date pits [20],langsat peel [34], apple waste [42], macadamia shell [57], rice husk [52], orange peel [58], prosopis juliflora plant [59], bamboo [60], corncob [41], coffee residue [61], pomegranate peel $[1,32]$, coconut shell $[11,62]$ etc. These agricultural waste have been investigated for various dye removal from aqueous solution such as basic dye [15,63-64], direct dye [11], benzidine-based dye [6], reactive dye [47,65] and others. Wan suraya et al. [44] have been studied the potential of sugarcane bagasse to be an alternative for conventional activated carbon. Sugarcane bagasse which is non-woody activated carbon are proven to be environmental friendly and low cost activated carbon and also efficient adsorption agent in removing dye and other pollutants from textile wastewater as compared to woody activated carbon $[35,38,44,64]$. Fig. 2 shown an example of structure surface for agricultural waste adsorbent. The use of agricultural waste in order to treat wastewater not only can solve environmental issue with inexpensive cost but also can reduce the 
agricultural waste in landfill as the waste can be reused.Agricultural waste is one of famous material to be used as activated carbon, however only few research are mention in this review as this review focusing on factors affect adsorption process.

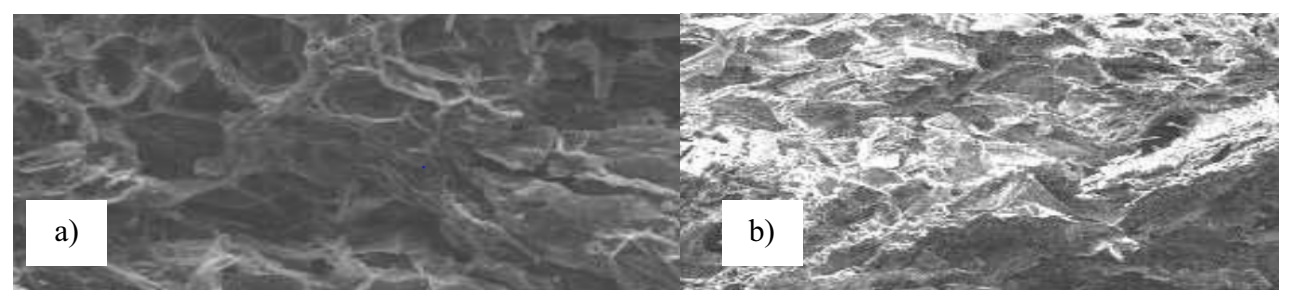

Fig. 2.Agricultural waste adsorbent SEM picture a) sugarcane bagasse activated carbon [38] b) raw sugarcane bagasse [38]

\subsection{Industrial waste}

Industrial waste also produce adsorbent that can be divided into two groups which are activated carbon solid waste and by-product. Sewage sludge is one of the adsorbent materials included in activated carbon solid waste categories. In addition, several sewage sludge based adsorbent has been used to remove pollutants [22,66-68]. These adsorbent can be produced using different activation process to adsorb metals and dye from wastewater [22]. Example of structure surface for industrial waste adsorbent can be shown as in Fig. 3. Research by Kacan and Kutahyali [67] analysed that the structure surface of sewage sludge prepared from chemical activation shortened the time of adsorption. As for industrial by product categories, fly ash and red mud is popular to be adsorbents materials [24,25]. Moreover, fly ash used in many countries even though it may contain some hazardous substance [25] because it is abundance and easily available material [36].There are lot of researcher also interest to studies on industrial waste but not all are listed in this review.

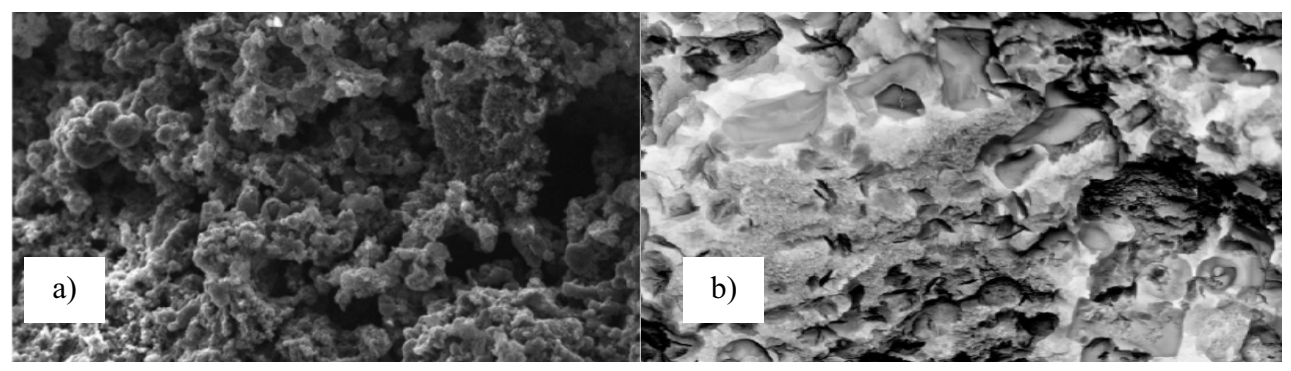

Fig. 3.Industrial waste adsorbent SEM picture a) sewage sludge activated carbon [67] b) usedtyre activated carbon [68]

\subsection{Biosorbent}

Biosorbent or sea material based adsorbent also has been studied by several researcher as an alternative material to treat wastewater [69-72]. Chitosan, algea and seafood waste are include in biosorbent materials [24] and example of surface structure for biosorbent is shown in Fig. 4. In Copello et al. [23] research, chitosan and chitin was used to remove three type of dye which is reactive dye (Reactive Black 5), basic dye (Basic Red 5 and Basic Violet 3) and acid dye (Acid Red 51). Other research explored the used of biomass of 
Trametes Virsicolor in eliminating direct dye which is benzidine based dye [70]. The result shown that heat-treat biomass adsorb more dye effectively as compared to native biomass for both direct blue 1 and direct red 128 dye. The maximum biosorption capacities of heattreat biomass recorded is $152.3 \mathrm{mg} / \mathrm{g}$ direct blue 1 and $225.4 \mathrm{mg} / \mathrm{g}$ for direct red 128. Das and Charumathi [71] mention that yeast have attractive futures as compared to fungi and bacteria with the ability to resist unfavourable environment and can rapidly growth. Miao et al. [72] research using alligator weed as activated carbon which produced a rough and high surface area, resulting high adsorption capacity.As same as agricultural waste and industrial waste, biosorbent also listed in researcher favourite subject but only few are mention in this review.

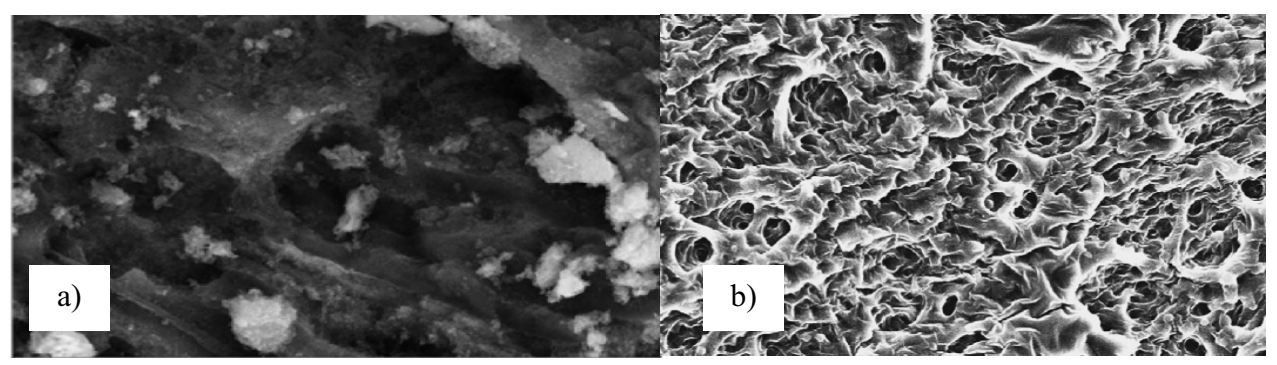

Fig. 4.Biosorbent SEM picture a) alligator weed activated carbon [71] b) fungus [70]

\section{Factor affecting adsorption}

Table 3 shows the operational parameter factors that affecting adsorption process conducted by other researchers. Dye adsorption can be affected by various factor like contact time, dosage of adsorbent, $\mathrm{pH}$ and initial dye concentration. These factors optimisation can be refer to be applied on full scale treatment process for eliminating dye. Thus, these parameters will be discussed in this review.

Table 3. Review on factors affecting adsorption studied by previous researchers.

\begin{tabular}{|c|c|c|c|c|c|c|c|c|}
\hline \multirow{2}{*}{$\begin{array}{ll}\text { Type } & \text { of } \\
\text { adsorbent }\end{array}$} & \multirow{2}{*}{$\begin{array}{l}\text { Type of } \\
\text { removal }\end{array}$} & \multicolumn{6}{|c|}{ Operational parameter factors } & \multirow[t]{2}{*}{ Ref. } \\
\hline & & $\begin{array}{l}\mathbf{p} \\
\mathbf{H}\end{array}$ & $\begin{array}{c}\text { Contact } \\
\text { time }\end{array}$ & $\begin{array}{l}\text { Adsorb } \\
\text { ent } \\
\text { concent } \\
\text { ration }\end{array}$ & Dosage & $\begin{array}{c}\text { Initial } \\
\text { dye } \\
\text { concentra } \\
\text { tion }\end{array}$ & $\begin{array}{c}\text { Temper } \\
\text { ature }\end{array}$ & \\
\hline $\begin{array}{l}\text { Raw bagasse and } \\
\text { modified bagasse }\end{array}$ & $\begin{array}{l}\text { Basic dye } \\
\text { (malachite } \\
\text { green) }\end{array}$ & & & $\checkmark$ & $\checkmark$ & & & [73] \\
\hline $\begin{array}{l}\text { Treated } \\
\text { sugarcane } \\
\text { bagasse and } \\
\text { powdered } \\
\text { activated carbon }\end{array}$ & $\begin{array}{l}\text { Acid dye } \\
\text { (acid red } \\
2 \text { ) }\end{array}$ & $\checkmark$ & & & $\checkmark$ & $\checkmark$ & & [8] \\
\hline $\begin{array}{l}\text { Modified } \\
\text { immobilized } \\
\text { activated alumina }\end{array}$ & $\begin{array}{l}\text { Reactive } \\
\text { dye } \\
\text { (reactive } \\
\text { yellow) }\end{array}$ & & $\checkmark$ & $\checkmark$ & $\checkmark$ & & & [74] \\
\hline $\begin{array}{l}\text { Fly ash bagasse } \\
\text { and commercial } \\
\text { activated carbon }\end{array}$ & $\begin{array}{l}\text { Basic dye } \\
\text { (malachite } \\
\text { green) }\end{array}$ & $\checkmark$ & $\checkmark$ & & $\checkmark$ & $\checkmark$ & & [26] \\
\hline
\end{tabular}


Table 3. Review on factors affecting adsorption studied by previous researchers. (Cont...)

\begin{tabular}{|c|c|c|c|c|c|c|c|c|}
\hline \multirow{2}{*}{$\begin{array}{l}\text { Type of } \\
\text { adsorbent }\end{array}$} & \multirow{2}{*}{$\begin{array}{l}\text { Type of } \\
\text { removal }\end{array}$} & \multicolumn{6}{|c|}{ Operational parameter factors } & \multirow[t]{2}{*}{ Ref. } \\
\hline & & $\begin{array}{l}\mathbf{p} \\
\mathbf{H}\end{array}$ & $\begin{array}{c}\text { Contact } \\
\text { time }\end{array}$ & $\begin{array}{l}\text { Adsorb } \\
\text { ent } \\
\text { concent } \\
\text { ration }\end{array}$ & Dosage & $\begin{array}{c}\text { Initial } \\
\text { dye } \\
\text { concentra } \\
\text { tion }\end{array}$ & $\begin{array}{c}\text { Temper } \\
\text { ature }\end{array}$ & \\
\hline $\begin{array}{l}\text { Cloth activated } \\
\text { carbon }\end{array}$ & Arsenic & $\checkmark$ & $\checkmark$ & $\checkmark$ & & $\checkmark$ & & {$[75]$} \\
\hline $\begin{array}{l}\text { Green vegetable } \\
\text { waste activated } \\
\text { carbon }\end{array}$ & Copper II & $\checkmark$ & $\checkmark$ & & $\checkmark$ & & & {$[76]$} \\
\hline $\begin{array}{l}\text { Orange peel } \\
\text { activated carbon }\end{array}$ & $\begin{array}{l}\text { Direct dye } \\
\text { (direct } \\
\text { navy blue } \\
106)\end{array}$ & $\checkmark$ & $\checkmark$ & & $\checkmark$ & $\checkmark$ & & {$[58]$} \\
\hline $\begin{array}{l}\text { Alligator weed } \\
\text { activated carbon }\end{array}$ & $\begin{array}{c}\text { Cephalexi } \\
n\end{array}$ & $\checkmark$ & $\checkmark$ & & $\checkmark$ & $\checkmark$ & $\checkmark$ & {$[72]$} \\
\hline $\begin{array}{l}\text { Coconut shell } \\
\text { activated carbon }\end{array}$ & $\begin{array}{c}\text { Reactive } \\
\text { dye } \\
\text { (reactive } \\
\text { blue 19) }\end{array}$ & $\checkmark$ & $\checkmark$ & & & $\checkmark$ & & {$[31]$} \\
\hline $\begin{array}{l}\text { Walnut activated } \\
\text { carbon and poplar } \\
\text { activated carbon }\end{array}$ & $\begin{array}{l}\text { Acid dye } \\
\text { (acid red } \\
18 \text { ) }\end{array}$ & $\checkmark$ & $\checkmark$ & & $\checkmark$ & & & {$[77]$} \\
\hline $\begin{array}{l}\text { Cryogenic } \\
\text { grinding used tyre } \\
\text { activated carbon }\end{array}$ & $\begin{array}{l}\text { Cationic } \\
\text { dye } \\
\text { (methylen } \\
\text { e blue) }\end{array}$ & $\checkmark$ & $\checkmark$ & & $\checkmark$ & $\checkmark$ & & {$[68]$} \\
\hline $\begin{array}{l}\text { Commercial } \\
\text { activated carbon }\end{array}$ & $\begin{array}{c}\text { Reactive } \\
\text { dye } \\
\text { (reactive } \\
\text { black 5) }\end{array}$ & $\checkmark$ & $\checkmark$ & & & $\checkmark$ & $\checkmark$ & {$[78]$} \\
\hline $\begin{array}{l}\text { Loofa sponge } \\
\text { activated carbon }\end{array}$ & $\begin{array}{l}\text { Cationic } \\
\text { dye } \\
\text { (methylen } \\
\text { e blue) } \\
\end{array}$ & $\checkmark$ & & & $\checkmark$ & $\checkmark$ & & {$[79]$} \\
\hline $\begin{array}{l}\text { Olive stone } \\
\text { activated carbon }\end{array}$ & $\begin{array}{l}\text { Cationic } \\
\text { dye } \\
\text { (methylen } \\
\text { e blue) }\end{array}$ & $\checkmark$ & $\checkmark$ & & & $\checkmark$ & & {$[80]$} \\
\hline $\begin{array}{l}\text { Ficus carica bast } \\
\text { activated carbon }\end{array}$ & $\begin{array}{l}\text { Cationic } \\
\text { dye } \\
\text { (methylen } \\
\text { e blue) } \\
\end{array}$ & $\checkmark$ & $\checkmark$ & & $\checkmark$ & $\checkmark$ & & {$[14]$} \\
\hline $\begin{array}{l}\text { Lansium } \\
\text { domesticum peel }\end{array}$ & $\begin{array}{l}\text { Cationic } \\
\text { dye } \\
\text { (methylen } \\
\text { e blue) }\end{array}$ & $\checkmark$ & $\checkmark$ & & $\checkmark$ & $\checkmark$ & & {$[34]$} \\
\hline $\begin{array}{l}\text { Raw wheat straw, } \\
\text { raw sawdust and } \\
\text { sugarcane } \\
\text { activated carbon }\end{array}$ & Fluoride & $\checkmark$ & $\checkmark$ & & $\checkmark$ & $\checkmark$ & & [55] \\
\hline
\end{tabular}




\subsection{Effect of contact time}

Generally, dye removal rate increase with an increase in contact time to a certain extent. Due to deposition of dyes on the available adsorption site on adsorbent material, any further increase in contact time will not increase the uptake [5]. At this point, the amount of dye desorbing form the adsorbent is in a state of dynamic equilibrium with the amount of dye being adsorbed onto the adsorbent. The time required to attain this state of equilibrium is termed the equilibrium time and the amount of dye adsorbed at the equilibrium time reflects the maximum adsorption capacity of the adsorbent under those operating conditions [34]. El-Sayed et al. [41] mention that contact time between adsorbent and adsorbate significantly affecting the performance of dye removal. As result in Fig. 5a, the removal was rapidly increase at the first $10 \mathrm{~min}$ but then slowly to obtain the equilibrium because of the strong attraction force between methylene blue dye and activated carbon. The time taken for corncob activated carbon with $400^{\circ} \mathrm{C}$ temperature of activation is $45 \mathrm{~min}$, while for $500^{\circ} \mathrm{C}$ and $600^{\circ} \mathrm{C}$ longer time needed which is $120 \mathrm{~min}$. The relation between direct blue 6 with contact time was studied in Khaled et al. [58] research. The time to reach equilibrium for orange peel activated carbon claim to be nearly $3 \mathrm{~h}$ for maximum adsorption to obtained as in Fig. 5b, with $\mathrm{pH}$ at 2 and dye concentration at range $50-150 \mathrm{mg} / \mathrm{L}$. The slow process was mention probably due to the slow of pore diffusion of solution ion into adsorbent bulk [58]. Based on theliterature information, the pattern of contact time effect for agricultural waste activated carbon are basically shown as in Fig. 5.

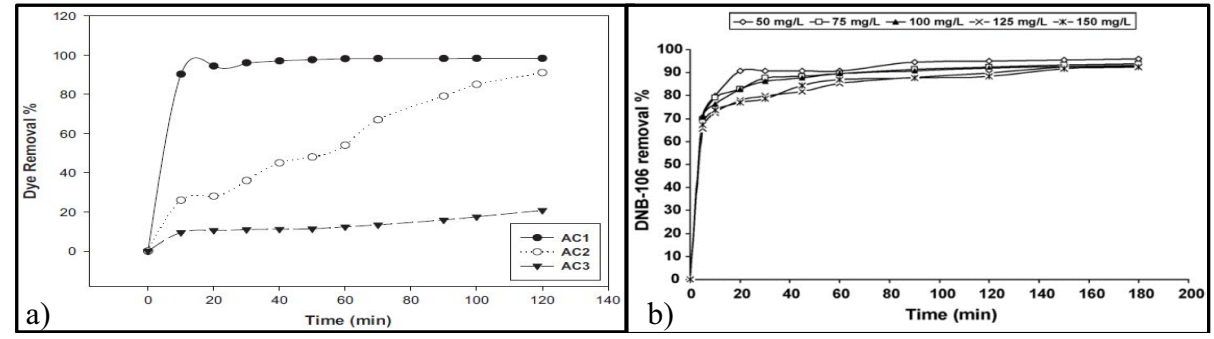

Fig. 5.Effect of contact time on dye removal using agricultural waste activated carbon from a) corncob [41] b) orange peel [58].

\subsection{Effect of adsorbent dose}

Dosage of adsorbent is one of important parameter in order to determine the adsorbent's capacity for a given amount of adsorbate at the operating conditions. In general, the increase in dye removal along with the increasing of adsorbent dose, where the amount of sorption site at the adsorbent surface will increase by increase of adsorbent dosage that will result on the increase of dye removal percentage [81]. In order to study the effect of adsorbent dose on the adsorption process, it can be carried out by preparing adsorbentadsorbate solution with different amount of adsorbents added to fixed initial dye concentration then shaken together until reach the equilibrium time [82]. Sharma and Uma [83] carried out an experiment using different dose of adsorbent $(0.40-0.60 \mathrm{~g})$ in $50 \mathrm{ml}$ of dye solution in order to find the effect on different rice husk activated carbon dosage to remove methylene blue. They reported that by increasing adsorbent dose from 0.40 to 0.60 $\mathrm{g}$, the percentage of removal increased from 86.75 to $99.83 \%$. Another researcher Heibati et al. [77] analysed the effect of adsorbent dose on the removal of acid red 18 (acid dye) by activated carbon from walnut (ACW) and poplar wood (ACP). The result shown as in Fig. 6a that the efficiency of dye removal increased as the adsorbent dosage increased up to 10 $\mathrm{mg} / \mathrm{g}$ and after that remain almost constant for both activated carbon. In Amin N.K [18] 
research on bagasse pith activated carbon to remove reactive dye, the same condition of result being detected. As in Fig. 6b, the percentage in removing reactive orange dye increased with the increase of adsorbent dose whereby the result may due to increment of dosage provides more surface area which lead to more biding site for adsorbent. Based on the literature review, analysing the effect of adsorbent dose showed the adsorption ability toward dye using minimum dosage of adsorbent. The rise in dosage provide more site for dye saturation during adsorption. Referring Fig. $6 \mathrm{a}$ and $6 \mathrm{~b}$, woody activated carbon optimum dose obtain at $1 \mathrm{~g}$ of adsorbent while non-woody activated carbon claimed the optimum dose to be at $15 \mathrm{~g}$ of adsorbent. The activated carbon from agricultural waste reviewedusing minimum dose of adsorbent and have a great potential in remove dye.

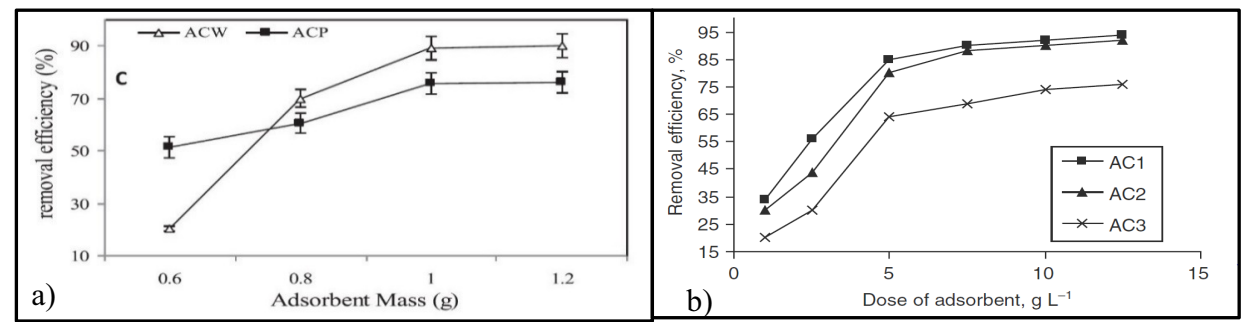

Fig. 6. Effect of adsorbent dose on dye removal using agricultural waste a) woody activated carbon [76] b) non-woody activated carbon [18]

\subsection{Effect of $\mathrm{pH}$}

The $\mathrm{pH}$ factor is very important for dye adsorption in the adsorption process. A medium $\mathrm{pH}$ will control the electrostatic charges magnitude which are imparted by ionized dye molecules and resulting the adsorption rate vary with the $\mathrm{pH}$ of the medium used $[68,84]$. Generally, dye removal percentage for cationic dye will decrease at a low $\mathrm{pH}$, while increment in dye removal percentage for ionic dyes adsorption. In contrast, cationic dye adsorption preferred for high solution of $\mathrm{pH}$ but as for anionic dye adsorption the efficiency will be lower [5]. As surface charge density decreases with an rising of $\mathrm{pH}$, the electrostatic repulsion between the positively charged dye and adsorbent surface is lowered, which may result in an increment in the adsorption extent [4,85-86]. Yasin et al. [85] investigated that in condition of $28^{\circ} \mathrm{C}$ of temperature with 180 min contact time and $0.25 \mathrm{~g} / 25 \mathrm{ml}$ dosage of adsorbent, the pattern as in Fig. 7a obtained for effect of $\mathrm{pH}$ on adsorption. The trends shown increment in methylene blue removal with the rising in $\mathrm{pH}$, while they predict that at the low $\mathrm{pH}$, the presence of $\mathrm{H}^{+}$ions competing with cations in dye for adsorption sites resulting lower adsorption [85]. Ahmad et al [32] reported that the effect of $\mathrm{pH}$ on the adsorption of remazol de by pomegranate activated carbon with the adsorption for the azo dye was initial at pH 3.6 and the maximum dye removal was at $94.36 \%$. In other research, N.K. Amin [18] studied the adsorption of reactive dyes on activated carbon from sugarcane bagasse which result obtained that the dye adsorption was maximum at intial $\mathrm{pH}$ of 1 and increment in $\mathrm{pH}$ decrease the percentage of dye removal as shown in Fig. 7b.Based on literature review, the increment of removal for cationic dye at high $\mathrm{pH}$ due to the decrement of positive charge at the solution interface which resulting the adsorbent surface to be negatively charged. As the increment of anionic dye adsorption at lower $\mathrm{pH}$ as result of adsorbent surface appear to be positively charged due to positive charge increament in solution interface.Fig. 7 shows the evidence where the percentage of dye removal for activated carbon was affected by $\mathrm{pH}$ variation. The strong force of interaction either $\mathrm{H}^{+}$or $\mathrm{OH}^{-}$ions between the activated carbon and the dye could influence the adsorption capacity [28]. 


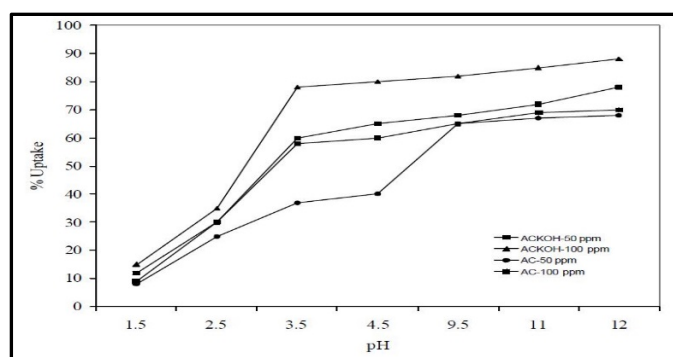

a)

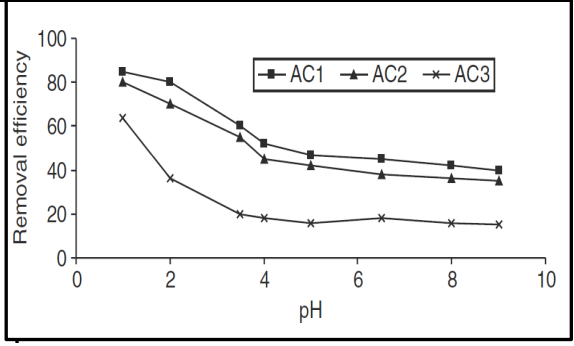

b)

Fig. 7.Effect of solution $\mathrm{pH}$ on removal of a) cationic dye [85] b) anionic dye [18] using agricultural waste activated carbon

\subsection{Effect of initial concentration}

A given mass of sorbent material can only adsorb a fixed amount of dye, hence the initial dye concentration of an effluent is one of important factor to studied [5]. The effect of dye initial concentration can be conducted by shaken adsorbent-adsorbate solution until equilibrium using fixed the adsorbent dosage with different initial dye concentration for different time intervals [82]. The effect of increment in dye initial concentration will increase the adsorbent loading capacity [81]. Amin N.K. [18] analysed the effect of initial dye concentration on removing reactive orange dye where the percentages of removal was noticed to be decrease. In research on Myrtus communis and pomegranate activated carbon [1], the different pattern was obtained. At concentration of $30 \mathrm{mg} / \mathrm{L}$ congo red, the percentage of removal was significantly increase with increment of congo red initial concentration. They concluded that by lowering the initial dye molecules, the adsorbent surface area will be low as well, hence the adsorption is depends on the initial concentration of dye [1]. Hazzaa and Hussein [80] reported that the increment of initial concentration enhance higher adsorption of dye as the driving force of mass transfer become large. Fig. $8 \mathrm{~b}$ shown the effect of initial concentration of dye in Hazzaa and Hussein [80] research where the risingof 50 to $150 \mathrm{mg} / \mathrm{L}$ initial concentration, the methylene blue adsorbed by olive stone activated carbon (OSAC) increased from 4.8 to $12.4 \mathrm{mg} / \mathrm{g}$ at $\mathrm{pH}$ of $5,25^{\circ} \mathrm{C}$ of temperature with $30 \mathrm{~min}$ contact time and $10 \mathrm{~g} / \mathrm{L}$ dosage of adsorbent.From the literature review, it is mention that the immediate relation between the available surfaces site on adsorbents and the concentration of dye affect the initial concentration factors [68]. As the initial concentration increase, the available site on adsorbent surface area become fewer which causingincrement in dye being adsorbed. However, the removal dye percentage decreased[8] which been proved in Fig. 8.

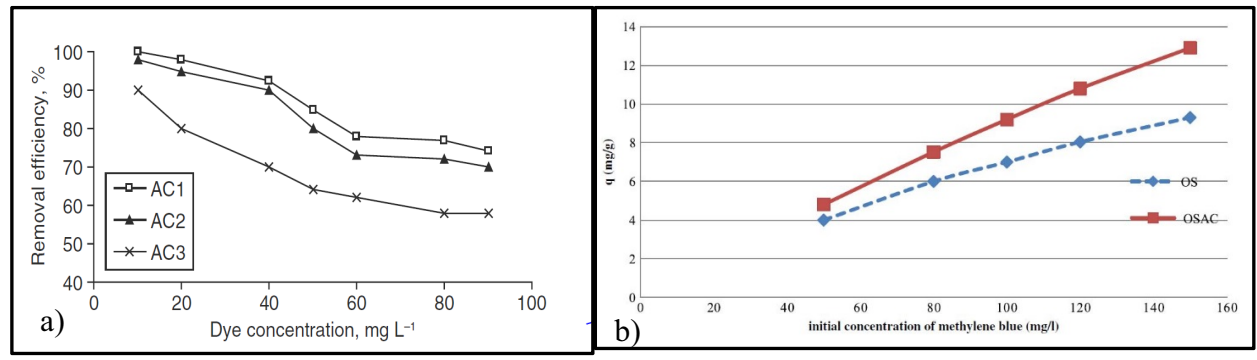

Fig. 8. Effect of initial concentration on removal of a) reactive dye [18] b) direct dye [80] by using agricultural activated carbon 


\section{Discussion}

Literature information give evident that activated carbon is the most preferred adsorbent material to treat wastewater that containing dyes and pigments. In addition, activated carbon prepared from agricultural waste came to be promising in the case of sugarcane bagasse, pomegranate peel, coconut shell [31-32,44,87]. Several activation process also been studied to improve the efficiency in removing dyes and pollutants in wastewater $[38,52,46,87-88]$. However, most of the study referred in this review referring to lab-scale experiment.Based on literature information, only few study focus on comparing the adsorbent in removal of dye and pollutants [25]. These problems may depends on the performance of material used. These easily available agricultural waste may have a variable characteristic of each materials and each of the materials or adsorbent has its own feature in the treatment for wastewater that will influence the adsorbent properties parameter. As example sugarcane bagasse effective in removing acid dye [35], grape marc-based in removing reactive dye [47] and coconut shell offer effective removal of basic dye but a bit lower for direct dye [11]. Yet, the variables and condition in adsorption process also influence the effectiveness of treatment including dose of adsorbent, contact time, adsorbent concentration, $\mathrm{pH}$ value and temperature. To ensure the adsorbent effectively can be used for industrial scale, further investigation on development of adsorption process for real condition of wastewater need to be conducted as the industrial effluents containing several pollutants simultaneously. Additional information on kinetic study and modelling is needed on this topic.Based on literature review, manyresearchers had beenstudy on adsorbent especially activated carbon. However they were focusing on the production of the activated carbon and those researches were not mentioned in this review. As for adsorption process study, environment condition is important as the effectiveness in removing dye depends to it. There a lot more factor that can affect the dye removal, however solution $\mathrm{pH}$, contact time, initial concentration and adsorbent dose gave the major affect in percentage of dye remove from wastewater.Further research is necessary,especially concentrate on the characteristics of adsorbents including the average size of particles and activation time to standardize the activated carbon. Besides that, more investigation should be conducted on benzidine-based dye (direct black 38, direct brown 95 and direct blue 6) as these dye is harmful to human, animals and environment. In addition, interest studies should be focus in real wastewater as majority of previous studies used synthetic solution to predict the performance of adsorption process towards removal of dye.

\section{Conclusion}

A review of various type of activated carbon as adsorbent has been presented. The use of these activated carbon as adsorbent is recommended since they show a good potential in eliminating dyes from industrial wastewater, easily available, low cost and renewable. This paper presented the potential of adsorption process using activated carbon from agricultural waste to remove dye from textile wastewater. The factors effecting dye adsorption such as contact time, adsorbent dosage, $\mathrm{pH}$ and initial dye concentration has been discussed. Solution of $\mathrm{pH}$ turn to be the most important condition in adsorption process as for anionic dye, a low $\mathrm{pH}$ value are preferable in contrast for cationic dye where the suitable $\mathrm{pH}$ value is high. For the adsorbent dose, that the adsorption capacity increase along with the increment of adsorbent dosage due to the increase of available amount of sorption site. Is was also highlighted that the contact time between adsorbent and dye affecting the efficiency of dye removal where strong attraction force will shortened the time.As for the effect of dye initial concentration, increasing the initial concentration, enhance the 
increment of adsorbent surface area to adsorb dyes.Extensive studies in literature show that industrial waste and biosorbent activated carbon are among the less selective compound in removing dye. Furthermore, agricultural waste activated carbon showed effectiveness in removing dye such as basic dye and direct dye yet often being test for other pollutant such as copper II, fluoride and phenol. However, the raw material of activated carbon to be used are depends on the local sources available at low cost. According to the literature reviewed, these adsorption method using agricultural waste activated carbon have potential to be applied at full-scale wastewater treatment. These low cost adsorbent can used to replace the expensive adsorbents in the market nowadays.

\section{References}

[1] M. Ghaedi, H. Tavallali, M. Sharifi, S.N. Kokhdan, and A. Asghari, Preparation of low cost activated carbon from Myrtus Communis and pomegranate and their efficient application for removal of congo red from aqueous solution, Spectrochimica Acta Part A,86, 107-114 (2012)

[2] V.K. Gupta and Suhas, Application of low-cost adsorbents for dye removal - A review, J. Environ. Manag.,90, 2313-2342 (2009)

[3] S.R. Couto, Dye removal by immobilised fungi, Biotech. Adv.,27, 227-235 (2009)

[4] S.J. Allen, and B. Koumanova, Decolourisation of water/wastewater using adsorption (review), J. University Chem. Technol. Metallurgy,40(3), 175-192 (2005)

[5] K.S. Bharathi and S.T. Ramesh, Removal of dyes using agricultural waste as low-cost adsorbents: a review, Appl. Water Sci.,3, 773-790 (2013)

[6] M.A. Kamboh, A.A. Bhatti, I.B. Solangi, S.T.H. Sherazi and S. Memon, Adsorption of direct black-38 azo dye on p-tert-butylcalix[6]areneimmobilized material, Arabian J. Chem.,7, 125-131 (2014)

[7] S. Lalnunhlimi and V. Krishnaswamy, Decolorization of azo dyes (Direct Blue 151 and Direct Red 31) by moderately alkaliphilic bacterial consortium, Brazilian J. Microbiology,47, 39-46 (2016)

[8] S.Saiful Azhar, A. Ghaniey Liew, D. Suhardy, K. Farizul Hafiz and MD. Irfan Hatim, Dye removal form aqueous solution by using adsorption on treated sugarcane bagasse, American J. Appl. Sci.,2(11), 1499-1503 (2005)

[9] A.E. Ghaly, R. Ananthashankar, M. Alhattab and V.V. Ramakrishnan, Production, characterization and treatment of textile effluents: a critical review, J. Chem. Eng. Process. Technol.,5, 1-18 (2014)

[10]A. Rehorek and A. Plum, Characterization of sulfonated azo dyes and aromatic amines by pyrolysis gas chromatography/mass spectrometry, Anal. Bioanal. Chem.,388, 1653$1662(2007)$

[11]A.M. Aljeboree, A.N. Alshirifi and A.F. Alkaim, Kinetics and equilibrium study for the adsorption of textile dyes on coconut shell activated carbon, Arabian J. Chem. In Press, (2014)

[12]B. Noroozi, G.A. Sorial, H. Bahrami and M. Arami, Adsorption of binary mixtures of cationic dyes, Dyes Pigm.,76, 784-791 (2008)

[13] W. Lemlikchi, N. Drouiche, N. Belaicha, N. Oubagha, B. Baaziz and M.O. Mecherri, Kinetic study of the adsorption of textile dyes on synthetic hydroxyapatite in aqueous solution, J. Ind. Eng. Chem., 32, 233-237 (2015)

[14]D. Pathania, A. Sharma and Z. Siddiqi, Removal of congo red dye from aqueous system using Pheonix dactylifera seeds, J. Molecular Liquids 219, 359-367 (2016)

[15]A.-A. Pelaez-cid, A.-M. Herrera-Gonzalez, M. Salazar-Villanueva and A. BoutistaHernandez, Elimination of textile dyes using activated carbons prepared from vegetable residues and their characterization, J. Environ. Manag., 181, 269-278 (2016) 
[16]B. Naresh, J. Jaydip, B. Prabhat and P. Rajkumar, Recent biological technologies for textile effluent treatment, Int. Res. J. Biol. Sci.,2(6), 77-82 (2013)

[17]M.S.I. Mozumder and M.A. Islam, Development of treatment technology for dye containing industrial wastewater, J. Sci. Rec.,2(3), 567-576 (2010)

[18]N.K. Amin, Removal of reactive dye from aqueous solutions by adsorption onto activated carbons prepared from sugarcane bagasse pith, Desalination,223, 152-161 (2008)

[19]P. Nigam, G. Armour, I.M. Banat, D. Singh and R. Marchant, Physical removal of textile dyes from effluents and solid-state fermentation of dye-adsorbed agricultural residues, Bioresour. Technol.,72, 219-226 (2000)

[20] S.S. Ashour, Kinetic and equilibrium adsorption of methylene blue and remazol dyes onto steam-activated carbons developed from date pits, J. Saudi Chem. Society,14, pp. 47-53 (2010)

[21] V.B. Upadhye and S.S. Joshi, Advances in wastewater treatment - A review, Int. J. Chemical Sci. Applications,3, 264-268 (2012)

[22] T.L. Silva, A. Ronix, O. Pezoti, L.S. Souza, P.K.T. Leandro, K.C. Bedin, K.K. Beltrame, A.L. Cazetta and V.C. Almeida, Mesoporous activated carbon from industrial laundry sewage sludge: adsorption studies of reactive dye remazol brilliant blue R, Chem. Eng. J.,303, 467-476 (2016)

[23] G.J. Copello, A.M. Mebert, M. Raineri, M.P. Pesenti and L.E. Diaz, Removal of dyes from water usning chitosan hydrogel/SiO2 and chitin hydrogel $/ \mathrm{SiO} 2$ hybrid materials obtained by the sol-gel method, J. Hazard. Mater.,186, 932-939 (2011)

[24] S.D. Gisi, G. Lorano, M. Grassi and M. Notarnicola, Characteristics and adsorption capacities of low-cost sorbents for wastewater treatment: a review, Sustainable Mater. Technol.,9, 10-40 (2016)

[25]G. Crini, Non-conventional low-cost adsorbents for dye removl: A review, Bioresour. Technol.,97, 1061-1085 (2006)

[26]I.D. Mall, V.C. Srivastava, N.K. Agarwal and I.M. Mishra, Adsorptive removal of malachite green dye from aueous solution by bagasse fly ash and activated carbonkinetic study and equilibrium isotherm analyses, Colloids Surf. A: Physicochem. Eng. Aspects, 264, 17-28 (2005)

[27]E. Clarke and R. Anliker, Organic dyes and pigments, Handb. Environ. Chem.,3, 181215 (1980)

[28]A. Demirbas, Agricultural based activated carbons for the removal of dyes from aqueous solutions: a review, J. Hazard. Mater.,167, 1-9 (2009)

[29]K.D. Belaid, S. Kacha, M. Kameche and Z. Derriche, Adsorption kinetics of some textile dyes onto granular activated carbon, J. Environ. Chemical Eng.,1, 496-503 (2013)

[30] M. Joshi, R. Bansal and R. Purwar, Colour removal from textile effluents, Indian J. Fibre Text. Res.,29, 239-259 (2004)

[31]U. Isah A., G. Abdulraheem, S. Bala, S. Muhammad and M. Abdullahi, Kinetics, equilibrium and thermodynamics studies of C.I. reactive blue 19 dye adsorption on coconut shell based activated carbon, Int. Biodeterioration Biodegradation,102, 265273 (2015)

[32]M.A. Ahmad, N.A. Ahmad Puad and O.S. Bello, Kinetics, equilibrium and thermodynamics studies ofsynthetic dye removal using pomegranate peel activated carbon prepared by microwave-induced $\mathrm{KOH}$ activation, Water Resc. Ind.,6, 18-35 (2014)

[33]E.R. Bandala, M.A. Pelaez, A.J. Gracia-Lopez, M.J. Salgado and G. Moeller, Photocatalytic decolourisation of synthetic and real textile wastewater containing benzidine-based azo dyes, Chem. Eng. Process.,47, 169-176 (2008) 
[34]M.A. Mohd Salleh, D. K. Mahmoud, N.A. Awang Abu, W.A. Wan Abdul Karim and A. Idris, Methylene blue adsorption from aqueous solution by langsat (lansium domesticum) peel, J. Purity, Utility Reaction Environ.,1, 472-495 (2012)

[35] W.T. Tsai, C.Y. Chang, M.C. Lin, S.F. Chien, H.F, Sun and M.F. Hsieh, Adsorption of acid dye onto activated carbons prepared from agricultural waste bagasse by $\mathrm{ZnCl} 2$ activation, Chemosphere,45, 51-58 (2001)

[36] S. Sivamani and B. Leena Grace, Removal of dyes from wastewater using adsorption A review, Int. J. BioSci. Technol.,2, pp. 47-51 (2009)

[37] S. Babel and T.A. Kurniawan, Low-cost adsorbents for heavy metals uptake from contaminated water: A review, J. Hazard. Mater.,97, 219-243 (2003)

[38]M. Valix, W.H. Cheung and G. McKay, Preparation of activated carbon using low temperature carbonisation and physical activation of high ash raw bagasse for acid dye adsorption, Chemosphere,56, 493-501 (2004)

[39] R. Zanzi, X. Bai, P. Capdevila and E. Bjornbom, Pyrolysis of biomass in presence of steam for production of activated carbon, liquid and gaseous fuels, Proc. of $6^{\text {th }}$ world congress on chemical engineering, Melbourne, Australia, 1-8 (2001)

[40]A.A. Mamun, Y.M. Ahmed, S.A. Muyibi, M.F.R. Al-Khatib, A.T. Jameel and M.A. Al-Saadi, Synthesis of carbon nanofibers on impregnated powdered activated carbon as cheap substrate, Arabian J. Chem.,9, 532-536 (2016)

[41] G.O. El-Sayed, M.M. Yehia and A.A. Asaad, Assessment of activated carbon prepared from corncob by chemical activation with phosphoric acid, Water Resc. Ind.,7-8, 66-75 (2014)

[42]R.H. Hesas, A. Arami-Niya, W.M.A. Wan Daud and J.N. Sahu, Preparation and characterization of activated carbon from apple waste by microwave-assisted phosphoric acid activation: Application in methylene blue adsorption, BioResour.,8(2), 2950-2966 (2013)

[43]H. Saygili, F. Guzel and Y. Onal, Conversion of grape industrial processing waste to activated carbon sorbent and its performance in cationic and anionic dyes adsorption, J. Cleaner Production,93, 84-93 (2015)

[44] R.W.S. Wan Suraya, M.R. Mohd Adib and H. Rafidah, Overview of acid optimization in impregnation method for sugarcane bagasse activated carbon production, Adv. Environ. Bio.,9(12) 1-5 (2015)

[45]K. Ahmadi, M. Ghaedi and A. Ansari, Comparison of nickel doped zinc sulphide and/or palladium nanoparticle loaded on activated carbon as efficient adsorbents for kinetic and equilibrium study of removal of congo red dye, Spectrochimica Acta Part A: Moecular and Biomolecular Spectroscopy,136, 1441-1449 (2015)

[46] S. Khamparia and D. Jaspal, Adsorptive removal of direct red 81 dye from aqueous solution onto Argemone Mexicana, Sustainable Environment Research (2016)

[47]H. Belayachi, B. Bestani, N. Benderdouche and M. Belhakem, The use of TiO2 immobilized into grape marc-based activated carbon for RB-5 azo dye photocatalytic degradation,Arabian J. Chem. In Press, (2015)

[48]C.X. Chen, B. Huang, T. Li and G.F. Wu,Preparation of phosphoric acid activated carbon from sugarcane bagasse by mechanochemical processing, Bioresour.,7(4), 5109-5116 (2012)

[49] N. Mohd Nor, T. Hadibarata, Z. Yusop and Z. Mat Lazim, Removal of brilliant green and procionred dyes from aqueous solution by adsorption using selected agricultural wastes, J. Teknologi (Sciences \& Engineering),74, 117-122 (2015)

[50]M.A. Yahya, Z. Al-Qodah and C.W. Zanariah Ngah, Agricultural bio-waste materials as potential sustainable precursors used for activated carbon production: A review, Renewable Sustainable Energy Reviews,46, 218-235 (2015) 
[51]Z. Zhang, L. Moghaddam, I.M. O'Hara and W.O.S. Doherty, Congo red adsorption by ball-milled sugarcanr bagasse, Chem. Eng. J.,178, 122-128 (2011)

[52]J.X. Yu, R.A. Chi, J. Guo, Y.F. Zhang, Z.G. Xu and C.Q. Xiao, Desorption and photodegradation of methylene blue from modified sugarcane bagasse surface by acid TiO2 hydrosol, Appl. Surf. Sci.,258, 4085-4090 (2012)

[53] S.L. Pandharipande, Y.D. Urunkar and A. Singh, Characterization and adsorption studies of activated carbon prepared from rice husk, sugarcane bagasse and saw dust, Int. J. Adv. Eng. Technol.,3(3), 60-62 (2012)

[54]H.D.S.S. Karunarathneand B.M.W.P.K. Amarasinghe, Fixed bed adsorption column studies for the removal of aqueous phenol from activated carbon prepared from sugarcane bagasse, Energy Procedia,34, 83-90 (2013)

[55] A.K. Yadav, R. Abbassi, A. Gupta and M. Dadashzadeh, Removal of floride from aqueous solution and groundwater by wheat straw, sawdust and activated bagasse carbon of sugarcane, Ecological Eng.,52, 211-218 (2013)

[56] S.M. Yakout and G. Sharaf El-Deen, Characterization of activated carbon prepared by phosphoric acid activation of olive stones, Arabian J. Chem, 9, S1155-S1162, (2016)

[57]N. Dejang, O. Somprasit and S. Chindaruksa, A preparation of atctivated carbon from macadamia shell by microwave irradiation activation, Energy Procedia,79, 727-732 (2015)

[58]A. Khaled, A. El-Nemr, A. El-Sikaily and O. Abdelwahab, Removal of direct N blue 106 from artificial textile dye effluent using activated carbon from orange peel: adsorption isotherm and kinetic studies, J. Hazard. Mater.,165, 100-110 (2009)

[59]A.J. Ahamed and K.R. Ahamed, Preparation and characterization of activated carbon from the Prosopis juliflora plant, Asian J. Chem.,20(3), 1702-1706 (2008)

[60]A.A. Ahmad and B.H. Hameed, Effect of preparation conditions of activated carbon from bamboo waste for real textile wastewater, J. Hazard. Mater. 173, 487-493 (2010)

[61] S.M. Lamine, C. Ridha, H.M. Mahfoud, C. Mouad, B. Lotfi and A.H. Al-Dujaili, Chemical activation of an activated carbon prepared from coffee residue, Energy Procedia 50, 393-400 (2014)

[62]N. Arena, J. Lee and R. Clift, Life cycle assessment of activated carbon production from coconut shells, J. Cleaner Production 125, 68-77 (2016)

[63]K.A.G. Gusmao, L.V.A. Gurgel, T.M.S. Melo and L.F. Gil, Application of succinylated sugarcane bagasse as adsorbents to remove methylene blue and gentian violet from aqueous solutions - kinetic and equilibrium studies, Dyes Pigm.,92, 967974 (2012)

[64] Y.S. Ho, W.T. Chiu and C.C. Wang, Regression analysis for the sorption isotherms of basic dyes on sugarcane dust, Bioresour. Technol.,96, 1285-1291 (2005)

[65]Z. Mat Lazim, N.S. Zulkifli, T. Hadibarata and Z. Yusop, Removal of cresol red and reactive black 5 dyes by using spent tea leaves and sugarcane bagasse powder, J. Teknologi (Sciences \& Engineering),74, 147-151 (2015)

[66]E. Kacan, Optimum BET surface ares for activated carbon produced from textile sewage sludges and its application as dye removal, J. Environ. Manag.,166, 116-123 (2016)

[67]E. Kacan and C. Kutahyali, Adsroption of strontium from aqueous solution using activated carbon produced from textile sewage sludges, J. Anal. Appl. Pyrolysis,97, 149-157 (2012)

[68]I. Ould Brahim, M. Belmedani, A. Belgacem, H. Hadoun and Z. Sadaoui, Discoloration of azo dye solutions by adsorption on activated carbon prepared from the cryogenic grinding of used tires, Chem. Eng. Transactions, 38, 121-126 (2014) 
[69] Y. Gao, S. Xu, Q. Y. Y. Wu and B. Gao, Chemical preparation of crab shell-based activated carbon with superior adsorption performance for dye removal from wastewater, J. Taiwan Institute Chem. Engineers,61, 327-335 (2016)

[70]G. Bayramoglu and M.Y. Arica, Biosorption of benzidine based textile dyes 'Direct Blue 1 and Direct Red 128" using native and heat-treated biomass of Trametes versicolor, J. Hazard. Mater.,143, 135-143 (2007)

[71]N. Das and D. Charumathi, Remediation of synthetic dyes from wastewater using yeast - An overview, Indian J. Biotech.,11, 369-380 (2012)

[72] M.S. Miao, Q. Liu, L. Shu, Z. Wang, Y.Z. Liu and Q. Kong, Removal of cephalexin from effluent by activated carbon prepared from alligator weed: kinetics, isotherms and thermodynamic analyses,Process Safety and Environmental Protection (2016)

[73]H. Tahir, M. Sultan, N. Akhtar, U. Hameed and T. Abid, Application of natural and modified sugarcane bagasse for the removal of dye from aqueous solution, J. Saudi Chem Society (2012)

[74] A. Wasti and M.A. Awan, J. Assoc. Arab Uni. Basic Appl. Sci.,20, 26-31 (2016)

[75]L. L. Matovic, N.S. Vukelic, U.D. Jovanovic, K.R. Kumric, J.B. Krstic, B.M. Babic and A.B. Dukic, Mechnochemically improved surface properties of activated carbon cloth for the removal of As(V) from aqueous solutions, Arabian J. Chem (2016)

[76] M.I. Sabela, K. Kunene, S. Kanchi, N.M. Xhakaza, A. Bathinapatla, P. Mdluli, D. Sharma and K. Bisetty, Removal of copper (II) from wastewater using green vegetable waste derived activated carbon: An approach to equilibrium and kinetic study, Arabian J. Chem. (2016)

[77]B. Heibati, S. Rodriguez-Couto, M.A. Al-Ghouti, M. Asif, I. Tyagi, S. Agarwal and V.K. Gupta, Kinetics and thermodynamics of enhanced adsorption of the dye AR 18 using activated carbons prepared from walnut and poplar woods, J. Molecular Liquid,208, 99-105 (2015)

[78]D.A. Giannakoudakis, G.Z. Kyzas, A. Avranas and N.K. Lazaridis, Multi-parametric adsorption effects of the reactive dye removal with commercial activated carbons, J. Molecular Liquids, 213, 381-389 (2016)

[79]H. Cherifi, B. Fatiha and H. Salah, Kinetic studies on the adsorption of the methylene blue onto vegetal fiber activated carbons, Appl. Surf. Sci.,282, 52-59 (2013)

[80]R. Hazzaa and M. Hussein, Adsorption of cationic dye from aqueous solution onto activated carbon prepared from olive stones, Environ. Technol. Innovation,4, 36-51 (2015)

[81] A.A. Adeyemo, I.O. Adeoye and O.S. Bello, Adsorption of dyes using different types of clay: a review, Appl. Water Sci. (2015)

[82] M.A. Mohd Salleh, D.K. Mahmoud, W.A. Wan Abdul Karim and A. Idris, Cationic and anionic dye adsorption by agricultural solid wastes: A comprehensive review, Desalination, 280, 1-13 (2011)

[83] Y.C. Sharma and S. Uma, Optimization of parameters for adsorption of methylene blue on a low-cost activated carbon, J. Chem. Eng. Data,55, 435-439 (2010)

[84]U.J. Etim, S.A. Umoren and U.M. Eduok, Coconut coir dust as a low cost adsorbent for the removal of cationic dye from aqueous solution, J. Saudi Chem. Society (2012)

[85]E. Yilmaz, S. Memon and M. Yilmaz, Removal of direct azo dyes and aromatic amines from aqueous solution using two $\beta$-cyclodecxtrin-based polymers, J. Hazard. Mater.,174, 592-597 (2010)

[86] Y. Yasin, M.Z. Hussein and F. Ahmad, Adsorption of methylene blue onto treated activated carbon, Malaysian J. Anal. Sci. 11(11), 400-406 (2007)

[87]Z. Nadzirah, H. Nor Haslina and M.R. Mohd Adib, Studies on the preparation of activated carbon sugarcane bagasse on removal of chemical oxygen demand, alkalinity and oil and grease of car wash wastewater, Adv. Environ. Biology, 9(12), 15-21 (2015) 
[88]K.A. Adegoke and O.S. Bello, Dye sequestration using agricultural wastes as adsorbents, Water Resour. Ind.,12, 8-24 (2015) 